JIKAP PGSD: Jurnal Ilmiah Ilmu Kependidikan

Vol,3. No,1. Tahun 2019

e-ISSN: 2597-4440 dan p-ISSN: 2597-4424

(c) (1) This work is licensed under a Creative Commons Attribution

4.0 International License

\title{
Penerapan Strategi Pembelajaran Billboard Ranking Guna Meningkatkan Prestasi Belajar Sejarah Materi Perkembangan Masyarakat Indonesia Pada Masa Reformasi Pada Siswa Kelas VII A SMP Negeri 1 Cenrana
}

\author{
Sudirman \\ Dinas Pendidikan Kabupaten Bone \\ Email: $\underline{\text { sudirman@gmail.com }}$
}

\begin{abstract}
Abstrak: Permasalahan yang ingin dikaji dalam penelitian ini adalah: (a) Bagaimanakah peningkatan prestasi belajar siswa dengan diterapkannya pembelajaran Billboard Ranking. (b) Bagaimanakah pengaruh metode pembelajaran Billboard Ranking terhadap prestasi belajar siswa. Tujuan dari penelitian tindakan ini adalah: (a) Ingin mengetahui peningkatan prestasi belajar siswa setelah diterapkannya pembelajaran Billboard Ranking . (b) Ingin mengetahui pengaruh motivasi belajar siswa setelah diterapkannya metode pembelajaran Billboard Ranking. Penelitian ini menggunakan penelitian tindakan (action research) sebanyak tiga putaran. Setiap putaran terdiri dari empat tahap yaitu: rancangan, kegiatan dan pengamatan, refleksi, dan refisi. Sasaran penelitian ini adalah siswa Kelas VII A. Tahun Pelajaran 2016/2017. Data yang diperoleh berupa hasil tes formatif, lembar observasi kegiatan belajar mengajar. Dari hasil analis didapatkan bahwa prestasi belajar siswa mengalami peningkatan dari siklus I sampai siklus III yaitu, siklus I (59\%), siklus II (79\%), siklus III (88\%). Kesimpulan dari penelitian ini adalah metode Billboard Ranking dapat berpengaruh positif terhadap motivasi belajar Siswa Kelas VII A. Pelajaran 2016/2017, serta metode pembelajaran ini dapat digunakan sebagai salah satu alternatif pembelajaran Sejarah.
\end{abstract}

Kata Kunci: Sejarah; Billboard Ranking

Abstract. Abstract. The problems that want to be studied in this study are: (a) How is the increase in student learning achievement by the application of Billboard Ranking learning. (b) What is the influence of the Billboard Ranking learning method on student learning achievement. The purpose of this action research is: (a) Want to know the improvement of student learning achievement after the implementation of Billboard Ranking learning. (b) Want to know the effect of student learning motivation after the implementation of the Billboard Ranking learning method. This study uses action research as many as three rounds. Each round consists of four stages, namely: design, activity and observation, reflection, and refining. The target of this study is students of Class VII A. Academic Year 2016/2017. Data obtained in the form of formative test results, observation sheets of teaching and learning activities. From the results of the 
analysis, it was found that student learning achievement had increased from cycle I to cycle III, namely, cycle I (59\%), cycle II (79\%), cycle III (88\%). The conclusion of this study is the Billboard Ranking method can have a positive effect on the learning motivation of Class VII A. Students in 2016/2017 lessons, and this learning method can be used as an alternative to learning history.

Keywords: History; Billboard Ranking.

\section{PENDAHULUAN}

Pendidikan merupakan hal yang sangat penting dan tidak bisa lepas dari kehidupan. Dengan pendidikan, kita bisa memajukan kebudayaan dan mengangkat derajat bangsa di mata dunia internasional. Pendidikan diartikan sebagai latihan mental,moral,dan fisik yang bisa menghasilkan manusia berbudaya tinggi maka pendidikan berarti menumbuhkan personalitas (kepribadian) serta menanamkan rasa tanggung jawab.

Tujuan Pendidikan Nasional yang tercantum dalam UU RI No. 20 Tahun 2003, yaitu: Pendidikan Nasional berdasarkan Pancasila dan Undang-undang Dasar 1945 bertujuan untuk mengembangkan potensi peserta didik agar menjadi manusia yang beriman dan bertaqwa kepada Tuhan Yang Maha Esa, erakhlaq mulia, sehat, berilmu, cakap, kreatif, mandiri, dan menjadi warga negara yang demokratis serta bertanggung jawab.

Strategi pembelajaran merupakan perencanaan yang berisi tentang rangkaian kegiatan yang disesuaikan untuk mencapai tujuan pendidikan tertentu. Dalam dunia pendidikan banyak sekali ragam strategi pembelajaran yang digunakan. Setiap strategi pembelajaran memiliki kelebihan dan kekurangan. Untuk itu setiap guru harus mampu memilih strategi pembelajaran yang tepat dalam menyampaikan materi yang berbeda agar tujuan pembelajaran tercapai dan maksimal.

Untuk itulah peneliti ingin meneliti sebuah strategi pembelajaran Billboard Ranking dimana kegiatan belajarnya lebih mempertimbangkan siswa, siswa diberikan kesempatan yang seluas-luasnya untuk mengembangkan diri, menurut pieget, siswa harus secara aktif berinteraksi dengan lingkungan belajarnya. Sehingga dapat membantu memperoleh pemahaman yang lebih tinggi.

Salah satu buktinya adalah penerapan strategi pembelajaran yang bervariasi, diantaranya adalah penerapan Strategi Billboard Ranking.yang telah diterapkan pada mata pelajaran Sejarahlangsung berhubungan dengan kehidupan nyata sehari-hari anak, jadi dapat menjadikan siswa lebih kritis terhadap masalah yang ada disekitarnya. Dan penggunaan Strategi Billboard Ranking dapat membantu siswa untuk lebih mudah mencapai tujuan belajar, sehingga siswa lebih mudah mendapatkan hasil belajar, dan dengan hasil belajar yang baik siswa bisa mencapai prestasi belajar yang tinggi.

\section{METODE PENELITIAN}

Penelitian ini merupakan penelitian tindakan (action research), karena penelitian dilakukan untuk memecahkan masalah pembelajaran di kelas. Penelitian ini juga termasuk penelitian deskriptif, sebab menggambarkan bagaimana suatu teknik pembelajaran diterapkan dan bagaimana hasil yang diinginkan dapat dicapai.

Tempat penelitian yang digunakan dalam penelitian ini bertempat di SMP Negeri 1 Cenrana dan penelitian ini dilaksanakan pada bulan September 2016 semester ganjil tahun ajaran 2016/2017. Sedangkan subyek penelitiannya adalah siswa-siswi Kelas VII A SMP Negeri 1 Cenrana tahun pelajaran 2016/2017.

Penelitian ini menggunakan Penelitian Tindakan Kelas (PTK). Penelitian tindakan ini menggunakan model penelitian tindakan dari Kemmis dan Taggart, yaitu berbentuk spiral dari sklus yang satu ke siklus yang berikutnya. Setiap siklus meliputi planning (rencana), action (tindakan), observation (pengamatan), dan reflection (refleksi). Berikut ini adalah 
tahap-tahap model penelitian tindakan dari Kemmis dan Taggart.

Instrumen yang digunakan dalam penelitian ini terdiri dari: (1) Silabus, (2) Rencana Pelajaran (RP), (3) Lembar Kegiatan Siswa, dan (4) Tes formatif. Selanjutnya, untuk analisis butir soal tes formatif mengikuti langkah-langkah adalah sebagai berikut:

a. Validitas Tes

Validitas butir soal atau validitas item digunakan untuk mengetahui tingkat kevalidan masing-masing butir soal. Sehingga dapat ditentukan butir soal yang gagal dan yang diterima. Tingkat kevalidan ini dapat dihitung dengan korelasi Product Moment:

$$
r_{x y}=\frac{N \sum X Y-\left(\sum X\right)\left(\sum Y\right)}{\sqrt{\left\{N \sum X^{2}-\left(\sum X\right)^{2}\right)\left(N \sum Y^{2}-\left(\sum Y\right)^{2}\right\}}}
$$

Dengan:

$\mathrm{r}_{\mathrm{xy}} \quad$ : Koefisien korelasi product moment

$\mathrm{N}:$ Kumlah peserta tes

$\Sigma \mathrm{Y} \quad$ : Jumlah skor total

$\Sigma \mathrm{X} \quad$ : Jumlah skor butir soal

$\Sigma X^{2} \quad$ : Jumlah kuadrat skor butir soal

$\Sigma X Y \quad$ : Jumlah hasil kali skor butir soal

b. Reliabilitas

Relaiabilitas butir sola dalam penelitian ini menggunakan rumus belah dua sebagai berikut:

$r_{11}=\frac{2 r_{1 / 21 / 2}}{\left(1+r_{1 / 21 / 2}\right)}($ Suharsimi Arikunto, 20001:

93) Dengan:

$\mathrm{r}_{11} \quad$ : Koefisien reliabilatas yang sudah disesuaikan

$\mathrm{r}_{1 / 21 / 2}$ :Korelasi antara skor-skor setiap belahan tes

Kriteria reliabilitas tes jika harga $\mathrm{r}_{11}$ dari perhitungan lebih besar dari harga $r$ pada tabel product moment maka tes tersebut reliable.

c. Taraf Kesukaran

Bilangan yang menunjukkan sukar dan mudahnya suatu soal adalah indeks kesukaran. Rumus yang digunakan untuk menentukan taraf kesukaran adalah:

$$
P=\frac{B}{J S}
$$

Dengan:

P : Indeks kesukaran
B : banyak siswa yang menjawab soal dengan benar

Js : Jumlah seluruh siswa peserta tes

Kriteria untuk menentukan indeks

kesukaran soal adalah sebagai berikut:

- Soal dengan $P=0,000$ sampai 0,300 adalah sukar

- Soal dengan $P=0,301$ sampai 0,700 adalah sedang

- Soal dengan $\mathrm{P}=0,701$ sampai 1,000 adalah mudah

d. Daya Pembeda

Daya pembeda soal adalah kemampuan suatu soal untuk membedakan antara siswa yang berkemampuan tinggi dengan siswa yang berkemampuan rendah. Angka yang menunjukkan besarnya daya pembeda desebut indeks diskriminasi. Rumus yang digunakan untuk menghitung indeks diskriminasi adalah sebagai berikut:

$$
D=\frac{B_{A}}{J_{A}}-\frac{B_{B}}{J_{B}}=P_{A}-P_{B}
$$

Dimana:

D : Indeks diskriminasi

$\mathrm{B}_{\mathrm{A}} \quad$ : Banyak peserta kelompok atas yang menjawab dengan benar

$\mathrm{B}_{\mathrm{B}} \quad$ : Banyak peserta kelompok bawah yang menjawab dengan benar

$\mathrm{J}_{\mathrm{A}} \quad$ : Jumlah peserta kelompok atas

$\mathrm{J}_{\mathrm{B}}$ : Jumlah peserta kelompok bawah $P_{A}=\frac{B_{A}}{J_{A}}=$ Proporsi peserta kelompok atas yang menjawab benar.

$$
P_{B}=\frac{B_{B}}{J_{B}}=\text { Proporsi peserta kelompok bawah }
$$

yang menjawab benar

Kriteria yang digunakan untuk menentukan daya pembeda butir soal sebagai berikut:

- Soal dengan D =0,000 sampai 0,200 adalah jelek

- Soal dengan $\mathrm{D}=0,201$ sampai 0,400 adalah cukup

- Soal dengan $\mathrm{D}=0,401$ sampai 0,700 adalah baik

- Soal dengan $\mathrm{D}=0,701$ sampai 1,000 adalah sangat baik 
Data-data yang diperlukan dalam penelitian ini diperoleh melalui observasi pengolahan metode pembelajaran aktif model meninjau kesulitan pada materi pelajaran, dan tes formatif.

Untuk mengetahui keefektivan suatu metode dalam kegiatan pembelajaran perlu diadakan analisa data. Pada penelitian ini menggunakan teknik analisis deskriptif kualitatif.

Untuk mengalisis tingkat keberhasilan atau persentase keberhasilan siswa setelah proses belajar mengajar setiap putarannya dilakukan dengan cara memberikan evaluasi berupa soal tes tertulis pada setiap akhir putaran. Analisis ini dihitung dengan menggunakan statistik sederhana yaitu:

1. Untuk menilai ulangan atau tes formatif

Peneliti melakukan penjumlahan nilai yang diperoleh siswa, yang selanjutnya dibagi dengan jumlah siswa yang ada di kelas tersebut sehingga diperoleh rata-rata tes formatif dapat dirumuskan:

$$
\bar{X}=\frac{\sum X}{\sum N}
$$

Dengan:

$$
\begin{array}{ll}
\bar{X} & =\text { Nilai rata-rata } \\
\Sigma \mathrm{X} & =\text { Jumlah semua nilai siswa } \\
\Sigma \mathrm{N} & =\text { Jumlah siswa }
\end{array}
$$

2. Untuk ketuntasan belajar
Ada dua kategori ketuntasan belajar yaitu secara perorangan dan secara klasikal. Seorang siswa telah tuntas belajar bila telah mencapai skor $65 \%$ atau nilai 65 , dan kelas disebut tuntas belajar bila di kelas tersebut terdapat $85 \%$ yang telah mencapai daya serap lebih dari atau sama dengan $65 \%$. Untuk menghitung persentase ketuntasan belajar digunakan rumus sebagai berikut:

$$
P=\frac{\sum \text { Siswa.yang.tuntas.belajar }}{\sum \text { Siswa }} \times 100 \%
$$

\section{HASIL DAN PEMBAHASAN}

\section{Siklus I}

a. Tahap Perencanaan

Pada tahap ini peneliti mempersiapkan perangkat pembelajaran yang terdiri dari rencana pelajaran 1, LKS 1 , soal tes formatif 1 , dan alat-alat pengajaran yang mendukung.

b. Tahap Kegiatan dan Pelaksanaan

Pelaksanaan kegiatan belajar mengajar untuk siklus I dilaksanakan pada tanggal 3 September 2016 di Kelas VII A dengan jumlah siswa 42 siswa. Dalam hal ini peneliti bertindak sebagai guru. Adapun proses belajar mengajar mengacu pada rencana pelajaran yang telah dipersiapkan. Pengamatan (observasi)

\begin{tabular}{|c|c|c|c|c|}
\hline \multirow[t]{2}{*}{ No } & \multirow[t]{2}{*}{ Aspek yang diamati } & \multicolumn{2}{|c|}{ Penilaian } & \multirow[t]{2}{*}{ Rata-rata } \\
\hline & & $\mathrm{P} 1$ & $\mathrm{P} 2$ & \\
\hline \multirow[t]{11}{*}{ I } & Pengamatan KBM & & & \\
\hline & A. Pendahuluan & & & \\
\hline & 1. Memotivasi siswa & 2 & 2 & 2 \\
\hline & 2. Menyampaikan tujuan pembelajaran & 3 & 2 & 2 \\
\hline & 3. Menghubungkan dengan pelajaran sebelumnya & 2 & 2 & 3 \\
\hline & 4. Mengatur siswa dalam kelompok-kelompok belajar & 2 & 2 & 2 \\
\hline & B. Kegiatan inti & & & \\
\hline & $\begin{array}{l}\text { 1. Mempresentasikan langkah-langkah metode } \\
\text { pembelajaran kooperatif }\end{array}$ & 2 & 2 & 2 \\
\hline & 2. Membimbing siswa melakukan kegiatan & 3 & 3 & 3 \\
\hline & 3. Melatih keterampilan kooperatif & 2 & 2 & 2 \\
\hline & $\begin{array}{l}\text { 4. Mengawasi setiap kelompok secara bergiliran } \\
\text { 5. Memberikan bantuan kepada kelompok yang } \\
\text { mengalami kesulitan }\end{array}$ & 3 & 3 & 3 \\
\hline
\end{tabular}
dilaksanakan bersamaan dengan pelaksanaan belajar mengajar. Adapun data hasil penelitian pada siklus I adalah sebagai berikut:

Tabel 4.1 Pengelolaan Pembelajaran Pada Siklus I 


\begin{tabular}{l|l|c|c|c}
\hline & C. Penutup & & & \\
& 1. Membimbing siswa membuat rangkuman & 3 & 3 & $\mathbf{3}$ \\
& 2. Memberikan evaluasi & 3 & 2 & $\mathbf{3}$ \\
\hline II & Pengelolaan Waktu & 2 & 2 & $\mathbf{2}$ \\
\hline III & Antusiasme Kelas & & & \\
& 1. Siswa antusias & 2 & 2 & $\mathbf{2}$ \\
& 2. Guru antisias & 3 & 2 & $\mathbf{2}$ \\
\hline & Jumlah & $\mathbf{3 0}$ & $\mathbf{2 9}$ & $\mathbf{3 0}$ \\
\hline
\end{tabular}

Keterangan: Nilai : Kriteria

1) : Tidak Baik

2) : Kurang Baik

3) : Cukup Baik

4) : Baik

Berdasarkan tabel di atas aspek-aspek yang mendapatkan kriteria kurang baik adalah memotivasi siswa, menyampaikan tujuan pembelajran, pengelolaan waktu, dan siswa antusias. Keempat aspek yang mendapat nilai kurang baik di atas, merupakan suatu kelemahan yang terjadi pada siklus I dan akan dijadikan bahan kajian untuk refleksi dan revisi yang akan dilakukan pada siklus II.

Tabel 4.2. Rekapitulasi Hasil Tes Siklus I

\begin{tabular}{c|l|c}
\hline No & \multicolumn{1}{|c|}{ Uraian } & Hasil Siklus I \\
\hline 1 & Nilai rata-rata tes & 69 \\
2 & formatif & 25 \\
3 & Jumlah siswa yang & $59 \%$ \\
& tuntas belajar & \\
& $\begin{array}{l}\text { Persentase ketuntasan } \\
\text { belajar }\end{array}$ \\
\hline
\end{tabular}

bahwa dengan menerapkan metode pembelajaran Billboard Ranking diperoleh nilai rata-rata prestasi belajar siswa adalah 69 dan ketuntasan belajar mencapai $59 \%$ atau ada 25 siswa dari 42 siswa sudah tuntas belajar. Hasil tersebut menunjukkan bahwa pada siklus pertama secara klasikal siswa belum tuntas belajar, karena siswa yang memperoleh nilai $\geq$ 65 hanya sebesar $59 \%$ lebih kecil dari persentase ketuntasan yang dikehendaki yaitu sebesar $85 \%$. Hal ini disebabkan karena siswa masih merasa baru dan belum mengerti apa yang dimaksudkan dan digunakan guru dengan menerapkan metode pembelajaran Billboard Ranking.

2. Siklus II

a. Tahap perencanaan

Pada tahap ini peneliti mempersiapkan perangkat pembelajaran yang terdiri dari rencana pelajaran 2, LKS 2, soal tes formatif II, dan alat-alat pengajaran yang mendukung.

b. Tahap kegiatan dan pelaksanaan

Pelaksanaan kegiatan belajar mengajar untuk siklus II dilaksanakan pada tanggal 01 September 2016 di kelas VII A dengan jumlah siswa42 siswa. Dalam hal ini peneliti bertindak sebagai guru. Adapun proses belajar mengajar mengacu pada rencana pelajaran dengan memperhatikan revisi pada siklus I, sehingga kesalahan atau kekurangan pada siklus I tidak terulang lagi pada siklus II. Pengamatan (observasi) dilaksanakan bersamaan dengan pelaksanaan belajar mengajar.

Pada akhir proses belajar mengajar siswa diberi tes formatif II dengan tujuan untuk mengetahui tingkat keberhasilan siswa selama proses belajar mengajar yang telah dilakukan. Instrument yang digunakan adalah tes formatif II. Adapun data hasil penelitian pada siklus II adalah sebagai berikut.

Tabel 4.3. Pengelolaan Pembelajaran Pada Siklus II

\begin{tabular}{c|l|l|l|l}
\hline No & \multicolumn{1}{|c|}{ Aspek yang diamati } & \multicolumn{2}{l|}{ Penilaian } & Rata-rata \\
\cline { 3 - 4 } & & P1 & P2 & \\
\hline I & Pengamatan KBM & & & \\
& D. Pendahuluan & 3 & 3 & $\mathbf{3}$ \\
& 1. Memotivasi siswa & 3 & 4 & $\mathbf{3}$ \\
& 2. Menyampaikan tujuan pembelajaran & 4 & 3 & $\mathbf{3}$ \\
& 3. Menghubungkan dengan pelajaran sebelumnya & 3 & 3 & $\mathbf{3}$ \\
& & 3 & 4 & $\mathbf{4}$ \\
\hline
\end{tabular}




\begin{tabular}{|c|c|c|c|c|}
\hline & $\begin{array}{l}\text { 4. Mengatur siswa dalam kelompok-kelompok } \\
\text { belajar }\end{array}$ & & & \\
\hline & $\begin{array}{l}\text { E. Kegiatan inti } \\
\text { 1. Mempresentasikan langkah-langkah metode } \\
\text { pembelajaran kooperatif } \\
\text { 2. Membimbing siswa melakukan kegiatan } \\
\text { 2. Melatih keterampilan kooperatif } \\
\text { 3. Mengawasi setiap kelompok secara bergiliran } \\
\text { 4. Memberikan bantuan kepada kelompok yang } \\
\text { mengalami kesulitan }\end{array}$ & $\begin{array}{l}3 \\
3 \\
4 \\
3 \\
3\end{array}$ & $\begin{array}{l}3 \\
4 \\
3 \\
4 \\
3\end{array}$ & $\begin{array}{l}4 \\
4 \\
4 \\
3\end{array}$ \\
\hline & $\begin{array}{l}\text { A. Penutup } \\
\text { 1. Membimbing siswa membuat rangkuman } \\
\text { 2. Memberikan evaluasi }\end{array}$ & $\begin{array}{l}3 \\
3\end{array}$ & $\begin{array}{l}3 \\
4\end{array}$ & $\begin{array}{l}3 \\
3\end{array}$ \\
\hline II & Pengelolaan Waktu & 3 & 3 & 3 \\
\hline III & $\begin{array}{l}\text { Antusiasme Kelas } \\
\text { 1. Siswa antusias } \\
\text { 2. } \text { Guru antisias }\end{array}$ & $\begin{array}{l}4 \\
4\end{array}$ & $\begin{array}{l}3 \\
4\end{array}$ & $\begin{array}{l}3 \\
4\end{array}$ \\
\hline & Jumlah & $\mathbf{5 0}$ & 51 & 50 \\
\hline
\end{tabular}

Keterangan: Nilai : Kriteria

1) : Tidak Baik

2) : Kurang Baik

3) : Cukup Baik

4) : Baik

Dari tabel di atas, tanpak aspek-aspek yang diamati pada kegiatan belajar mengajar (siklus II) yang dilaksanakn oleh guru dengan menerapkan metode pembelajarn kooperatif model Billboard Ranking mendapatkan penilaian yang cukup baik dari pengamat. Namun demikian penilaian tesebut belum merupakan hasil yang optimal, untuk itu ada beberapa aspek yang perlu mendapatkan perhatian untuk penyempurnaan penerapan pembelajaran selanjutnya. Aspek-aspek tersebut adalah memotivasi siswa, membimbing siswa merumuskan kesimpulan/ menemukan konsep, dan pengelolaan waktu.

Tabel 4.4. Rekapitulasi Hasil Tes Siklus I

\begin{tabular}{c|l|c}
\hline No & \multicolumn{1}{|c|}{ Uraian } & Hasil Siklus I \\
\hline 1 & Nilai rata-rata tes & 73 \\
2 & formatif & 33 \\
3 & Jumlah siswa & $79 \%$ \\
& yang tuntas & \\
& belajar & \\
& Persentase & \\
& ketuntasan belajar & \\
\end{tabular}

Dari tabel di atas diperoleh nilai ratarata prestasi belajar siswa adalah 69,77 dan ketuntasan belajar mencapai $79 \%$ atau ada 33 siswa dari 42 siswa sudah tuntas belajar. Hasil ini menunjukkan bahwa pada siklus II ini ketuntasan belajar secara klasikal telah megalami peningkatan sedikit lebih baik dari siklus I. Adanya peningkatan hasil belajar siswa ini karena setelah guru menginformasikan bahwa setiap akhir pelajaran akan selalu diadakan tes sehingga pada pertemuan berikutnya siswa lebih termotivasi untuk belajar. Selain itu siswa juga sudah mulai mengerti apa yang dimaksudkan dan diinginkan guru dengan menerapkan metode pembelajaran Billboard Ranking.

3. Siklus III

a. Tahap Perencanaan

Pada tahap ini peneliti mempersiapkan perangkat pembelajaran yang terdiri dari rencana pelajaran 3, LKS 3, soal tes formatif 3, dan alat-alat pengajaran yang mendukung

b. Tahap kegiatan dan pengamatan

Pelaksanaan kegiatan belajar mengajar untuk siklus III dilaksanakan pada tanggal 20 September 2016 di Kelas VII A. dengan jumlah siswa 42 siswa. Dalam hal ini peneliti bertindak sebagai guru. Adapun proses belajar mengajar mengacu pada rencana pelajaran dengan memperhatikan revisi pada siklus II, sehingga kesalahan atau kekurangan pada siklus II tidak terulang lagi pada siklus III. Pengamatan 
(observasi) dilaksanakan bersamaan dengan pelaksanaan belajar mengajar.

Pada akhir proses belajar mengajar siswa diberi tes formatif III dengan tujuan untuk mengetahui tingkat keberhasilan siswa dalam proses belajar mengajar yang telah dilakukan. Instrumen yang digunakan adalah tes formatif III. Adapun data hasil peneitian pada siklus III adalah sebagai berikut:

Tabel 4.5. Pengelolaan Pembelajaran Pada Siklus III

\begin{tabular}{|c|c|c|c|c|}
\hline \multirow[t]{2}{*}{ No } & \multirow[t]{2}{*}{ Aspek yang diamati } & \multicolumn{2}{|c|}{ Penilaian } & \multirow[t]{2}{*}{ Rata-rata } \\
\hline & & P1 & $\mathrm{P} 2$ & \\
\hline \multirow[t]{3}{*}{$\mathbf{I}$} & $\begin{array}{l}\text { Pengamatan KBM } \\
\text { A. Pendahuluan } \\
\text { 1. Memotivasi siswa } \\
\text { 2. Menyampaikan tujuan pembelajaran } \\
\text { 3. Menghubungkan dengan pelajaran sebelumnya } \\
\text { 4. Mengatur siswa dalam kelompok-kelompok belajar }\end{array}$ & $\begin{array}{l}4 \\
4 \\
4 \\
4\end{array}$ & $\begin{array}{l}4 \\
4 \\
4 \\
4\end{array}$ & $\begin{array}{l}4 \\
4 \\
4 \\
4\end{array}$ \\
\hline & $\begin{array}{l}\text { B. Kegiatan inti } \\
\text { 1. Mempresentasikan langkah-langkah metode } \\
\text { pembelajaran kooperatif } \\
\text { 2. Membimbing siswa melakukan kegiatan } \\
\text { 3. Melatih keterampilan kooperatif } \\
\text { 4. Mengawasi setiap kelompok secara bergiliran } \\
\text { 5. Memberikan bantuan kepada kelompok yang } \\
\text { mengalami kesulitan }\end{array}$ & $\begin{array}{l}4 \\
3 \\
4 \\
3\end{array}$ & $\begin{array}{l}4 \\
3 \\
4 \\
3 \\
4\end{array}$ & $\begin{array}{l}3 \\
3 \\
4 \\
4 \\
4\end{array}$ \\
\hline & $\begin{array}{l}\text { C. Penutup } \\
\text { 1. Membimbing siswa membuat rangkuman } \\
\text { 2. Memberikan evaluasi }\end{array}$ & $\begin{array}{l}4 \\
4\end{array}$ & $\begin{array}{l}4 \\
4\end{array}$ & $\begin{array}{l}4 \\
4\end{array}$ \\
\hline II & Pengelolaan Waktu & 4 & 4 & 4 \\
\hline III & $\begin{array}{l}\text { Antusiasme Kelas } \\
\text { 1. Siswa antusia } \\
\text { 2. Guru antisias }\end{array}$ & $\begin{array}{l}4 \\
4\end{array}$ & $\begin{array}{l}4 \\
4\end{array}$ & $\begin{array}{l}4 \\
4\end{array}$ \\
\hline & Jumlah & 54 & 54 & 54 \\
\hline
\end{tabular}

Keterangan: Nilai : Kriteria

$$
\begin{array}{ll}
\text { 1. } & \text { : Tidak Baik } \\
\text { 2. } & \text { : Kurang Baik } \\
\text { 3. } & \text { : Cukup Baik } \\
\text { 4. } & \text { : Baik }
\end{array}
$$

Dari tabel di atas, dapat dilihat aspekaspek yang diamati pada kegiatan belajar mengajar (siklus III) yang dilaksanakan oleh guru dengan menerapkan metode pembelajaran kooperatif model Pengembangan Pembiasaan mendapatkan penilaian cukup baik dari pengamat adalah memotivasi siswa, membimbing siswa merumuskan kesimpulan/menemukan konsep, dan pengelolaan waktu.

Penyempurnaan aspek-aspek diatas dalam menerapkan metode pembelajaran kooperatif model Billboard Ranking diharapkan dapat berhasil semaksimal mungkin.
Tabel 4.6. Rekapitulasi Hasil Tes Siklus I

\begin{tabular}{|c|l|c|}
\hline No & \multicolumn{1}{|c|}{ Uraian } & Hasil Siklus I \\
\hline 1 & Nilai rata-rata tes & 76 \\
2 & formatif & 20 \\
3 & Jumlah siswa yang & $88 \%$ \\
& tuntas belajar & \\
& $\begin{array}{l}\text { Persentase } \\
\text { ketuntasan belajar }\end{array}$ \\
\hline
\end{tabular}

Berdasarkan tabel diatas diperoleh nilai rata-rata tes formatif sebesar 76 dan dari 42 siswa yang telah tuntas sebanyak 37 siswa dan 2 siswa belum mencapai ketuntasan belajar. Maka secara klasikal ketuntasan belajar yang telah tercapai sebesar 88\% (termasuk kategori tuntas). Hasil pada siklus III ini mengalami peningkatan lebih baik dari siklus II. Adanya peningkatan hasil belajar pada siklus III ini dipengaruhi oleh adanya peningkatan kemampuan guru dalam 
menerapkan pembelajaran Billboard Ranking sehingga siswa menjadi lebih terbiasa dengan pembelajaran seperti ini sehingga siswa lebih mudah dalam memahami materi yang telah diberikan. Pada siklus III ini ketuntasan secara klasikal telah tercapai, sehingga penelitian ini hanya sampai pada siklus III.

c. Refleksi

Pada tahap ini akah dikaji apa yang telah terlaksana dengan baik maupun yang masih kurang baik dalam proses belajar mengajar dengan penerapan pembelajaran Billboard Ranking. Dari data-data yang telah diperoleh dapat duraikan sebagai berikut:

1) Selama proses belajar mengajar guru telah melaksanakan semua pembelajaran dengan baik. Meskipun ada beberapa aspek yang belum sempurna, tetapi persentase pelaksanaannya untuk masing-masing aspek cukup besar.

2) Berdasarkan data hasil pengamatan diketahui bahwa siswa aktif selama proses belajar berlangsung.

3) Kekurangan pada siklus-siklus sebelumnya sudah mengalami perbaikan dan peningkatan sehingga menjadi lebih baik.

4) Hasil belajar siswa pada siklus III mencapai ketuntasan.

d. Revisi Pelaksanaan

Pada siklus III guru telah menerapkan pembelajaran Billboard Ranking dengan baik dan dilihat dari aktivitas siswa serta hasil belajar siswa pelaksanaan proses belajar mengajar sudah berjalan dengan baik. Maka tidak diperlukan revisi terlalu banyak, tetapi yang perlu diperhatikan untuk tindakan selanjutnya adalah memaksimalkan dan mepertahankan apa yang telah ada dengan tujuan agar pada pelaksanaan proses belajar mengajar selanjutnya penerapan pembelajaran Billboard Ranking dapat meningkatkan proses belajar mengajar sehingga tujuan pembelajaran dapat tercapai.

1. Ketuntasan Hasil belajar Siswa

Melalui hasil peneilitian ini menunjukkan bahwa pembelajaran Billboard Ranking memiliki dampak positif dalam meningkatkan prestasi belajar siswa. Hal ini dapat dilihat dari semakin mantapnya pemahaman siswa terhadap materi yang disampaikan guru (ketuntasan belajar meningkat dari sklus I, II, dan II) yaitu masingmasing 59\%, 79\%, dan $88 \%$. Pada siklus III ketuntasan belajar siswa secara klasikal telah tercapai.

2. Kemampuan Guru dalam Mengelola Pembelajaran

Berdasarkan analisis data, diperoleh aktivitas siswa dalam proses pembelajaran Billboard Ranking dalam setiap siklus mengalami peningkatan. Hal ini berdampak positif terhadap prestasi belajar siswa yaitu dapat ditunjukkan dengan meningkatnya nilai rata-rata siswa pada setiap siklus yang terus mengalami peningkatan.

3. Aktivitas Guru dan Siswa Dalam Pembelajaran

Berdasarkan analisis data, diperoleh aktivitas siswa dalam proses pembelajaran Sejarah pada pokok bahasan sumber daya alam yang paling dominan adalah bekerja dengan menggunakan alat/media, mendengarkan/memperhatikan penjelasan guru, dan diskusi antar siswa/antara siswa dengan guru. Jadi dapat dikatakan bahwa aktivitas siswa dapat dikategorikan aktif.

Sedangkan untuk aktivitas guru selama pembelajaran telah melaksanakan langahlangkah pembelajaran Billboard Ranking dengan baik. Hal ini terlihat dari aktivitas guru yang muncul di antaranya aktivitas membimbing dan mengamati siswa dalam mengerjakan kegiatan LKS/menemukan konsep, menjelaskan/melatih menggunakan alat, memberi umpan balik/evaluasi/tanya jawab dimana prosentase untuk aktivitas di atas cukup besar.

\section{SIMPULAN DAN SARAN}

Dari hasil kegiatan pembelajaran yang telah dilakukan selama tiga siklus, dan berdasarkan seluruh pembahasan serta analisis yang telah dilakukan dapat disimpulkan sebagai berikut:

1. Pembelajaran dengan Billboard Ranking memiliki dampak positif dalam meningkatkan prestasi belajar siswa yang ditandai dengan peningkatan ketuntasan belajar siswa dalam setiap siklus, yaitu siklus I (59\%), siklus II (79\%), siklus III (88\%). 
2. Penerapan metode pembelajaran Billboard Ranking mempunyai pengaruh positif, yaitu dapat meningkatkan motivasi belajar siswa.

Dari hasil penelitian yang diperoleh dari uraian sebelumnya agar proses belajar mengajar Sejarah lebih efektif dan lebih memberikan hasil yang optimal bagi siswa, maka disampaikan saran sebagai berikut:

1. Untuk melaksanakan Metode Billboard Ranking memerlukan persiapan yang cukup matang, sehingga guru harus mampu menentukan atau memilih topik yang benarbenar bisa diterapkan dengan Metode Billboard Ranking.

2. Dalam rangka meningkatkan prestasi belajar siswa, guru hendaknya lebih sering melatih siswa dengan berbagai metode pembelajaran.

3. Perlu adanya penelitian yang lebih lanjut, karena hasil penelitian ini hanya dilakukan di sekolah SMP Negeri 1 Cenrana Tahun Pelajaran 2016/2017.

\section{DAFTAR RUJUKAN}

Arifin, Zaenal. 1999. Evaluasi Instruksional, Bandung : PT. Remaja Rosdakarya

Arikunto, Suharsimi. 1996. Dasar-dasar Evaluasi Pendidikan, Jakarta: Bumi Aksara

Arikunto, Suharsimi. 2002. Prosedur Penelitian Suatu Pendekatan Praktek, Jakarta: PT. Rineka Cipta

Azwar, Saifudin. 2007. Metode Penelitian, Yogyakarta: Pustaka Pelajar

Buchori, M. 1990. Evaluasi InstruksionalPrinsip \& Teknik Pendidikan, Bandung: PT. Remaja Rosdakarya

Dalyono, M. 1997. Psikologi Pendidikan, Jakarta: Rineka Cipta

Darajat, Zakiyah. 1992. Ilmu Pendidikan Islam, Jakarta: Bumi Aksara

Darajat, Zakiyah. 1995. Metodik Khusus Pengajaran Agama Islam, Jakarta: Bumi Aksara

Dimyati dan Mujiono. 1999. Mengajar dan Pembelajaran, Jakarta: Rineka Cipta

Djamarah, Syaiful Bahri, Aswan Zaini. 1994. Strategi Belajar Mengajar, Jakarta: Rineka Cipta
Djamarah, Syaiful Bahri. 1994. Prestasi Belajar dan Kompetesi Guru, Jakarta: Rineka Cipta

Hadi, Sutrisno. 1990. Metodologi Research II, Yogyakarta: Andi Offset

Hasan, Mas'ud. 1998. Kamus Ilmiah Populer, Surabaya: Bintang Pelajar

Mardalis.1997. Metodologi Penelitian Suatu Pendekatan Proposal, Jakarta: Bumi Aksara

Mulyasa, E. 2003. Kurikulum Berbasis Kompetensi, Konsep Karakteristik dan Implementasi, Bandung : Remaja Rosdakarya

Mulyasa, E. 2006. Menjadi Guru Profesional, Bandung: Remaja Rosdakarya

Nasution, S. Azaz-azas Mengajar, Bandung: Jemnas, tt Netra, I.B. 1974. Statistik Inferensial, Surabaya: Usaha Nasional

Partanto, Pins A. dan M. Dahlan Al-Barry. 1994. Kamus Ilmiah Populer, Surabaya: Arkola

Ramayulism. 1995. Profesionalitas Guru Agama Antara Harapan dan Kenyataan, Makalah disampaikan dalam seminar sehari Profesionalitas Guru Agama. Universitas Ahlusunnah Bukittingi

Ramayulis. 2004. Ilmu Sejarah, Jakarta: Kalam Mulia

Ramayulis. 2005. Metodologi Sejarah, Jakarta: Kalam Mulia

Rohani, Ahmad. 1995. Pengelolaan Pengajaran, Jakarta: Rineka Cipta

Sanjaya, Wina. 2006. Strategi Pembelajaran, Jakarta: Kencana Predana Media

Silberman, Mel. 2002. Active Learning 101 Strategi Pembelajaran Aktif, Yogyakarta:

Pustaka Insan Madani

Slameto. 1991. Proses Belajar Mengajar dalam Sistem Kredit Semester, Jakarta: Bumi Aksara

Slameto. 1997. Belajar dan Faktor-faktor yang Mempengaruhinya, Jakarta: Rineka Cipta

Soemanto, Wasty. 1990. Psikologi Pendidikan, Jakarta: Rineka Cipta

Sriyono Dkk. 1992. Teknik Belajar Mengajar Dalam CBSA, Jakarta: Rineka Cipta 
JIKAP PGSD: Jurnal Ilmiah Ilmu Kependidikan

Sudjana, Nana. 1989. Penilaian Hasil Proses Belajar Mengajar, Bandung: PT.

Remaja Rosdakarya

Syah, Muhibbin. 1997. Psikologi Pendidikan dengan Pendekatan Baru. Bandung: PT. Remaja Rosdakarya

Syah, Muhibbin. 2006. Psikologi Belajar, Jakarta: PT RajaGrafindo Persada Tim Pusat Pembinaan dan Pengembangan Bahasa, 1996

Tirtonegoro, Sutartinah. 1984. Anak Supernormal \& Program Pendidikannya, Jakarta: Bina Aksara

Usman, Moh Uzer, Lilis Setiawati. 1999. Upaya Optimalisasi Kegiatan Belajar Mengajar, Bandung: PT. Remaja Rosdakarya

Walpole, Ronald. E. 1995. Pengantar Statistik, Jakarta: PT Gramedia Pustaka Utama

Zaini, Hisyam. 2008. Strategi Pembelajaran Aktif, Yogyakarta: Pustaka Insan 